\title{
NA COVA DE CAL
}

\author{
Alan Cichela \\ DOI: http://dx.doi.org/10.18616/intcov49
}

\begin{abstract}
A solidão me provoca;
me coloca (de frente);

me faz pensar;

me faz agir.
\end{abstract}

Eu sento e me olho;

vejo todos os sentimentos,

sem qualquer excitação,

sei que estou só.

Solidão

(estar só) é

estar de frente

a um muro.

Na cova,

isolamento.

revestido de cal,

O

o odor matinal.

$\mathrm{S}$

$U$

M

Á

$\mathrm{R}$

O 